\title{
Analisis Isi Pesan dakwah dalam Tanbih TQN PP. Suryalaya
}

\author{
Ahmadi* $^{*}$ \\ ${ }^{1}$ Komunikasi dan Penyiaran Islam, Pascasarjana UIN Sunan Gunung \\ Djati Bandung \\ *Email : ahmadisirnarasa38@gmail.com
}

\begin{abstract}
ABSTRAK
Dengan perkembangan zaman, media (wasilah) dakwah semakin banyak, salah satunya ialah melalui media tulisan (dakwah bil qolam). penelitin ini adalah untuk menganalisis isi pesan dakwah dalam Tanbih TQN PP. Suryalaya yang ditulis oleh Syaikh Abdulloh Mubarok bin Nur Muhammad pada tahun 1956 M. Metode yang dipakai dalam penelitian ini adalah analisis isi, dan teknik pengumpulan datanya, yaitu dengan mencari data mengenai hal-hal yang berkaitan dengan masalah-masalah yang akan diteliti berupa catatan, buku, surat kabar serta data penunjang lainya yang berhubungan dengan masalah penelitian, serta data yang bersumber dari Tanbih TQN PP. Suryalaya. Hasil penelitian menemukan bahwah isi pesan meliputi masalah keyakinan dalam beragama (aqidah), ketaatan terhadap agama dan negara (syariat ubudiyah dan siayat) dan etika dalam bergaul sesama manusia sekalipun orang asing dan non-muslim (akhlaq). Kesimpulannya, bahwa pesan dakwah dalam Tanbih TQN PP. Suryalaya yang ditulis pada tahun 1956 M menyimpan bimbingan hidup dalam beragama dan bernegara.
\end{abstract}

Kata Kunci : Pesan, Dakwah; Tanbih TQN PP. Suryalaya 


\begin{abstract}
With the development of the times, the media (wasilah) of da'wah is increasing, one of which is through written media (da'wah bil qolam). This research is to analyze the content of the message of $d a^{\prime}$ wah in Tanbih TQN PP. Suryalaya written by Sheikh Abdulloh Mubarok bin Nur Muhammad in 1956 AD The method used in this research is content analysis, and data collection techniques, namely by looking for data on matters relating to the problems to be studied in the form of notes, books, newspapers and other supporting data related to research problems, as well as data sourced from Tanbih TQN PP. Suryalaya. The results of the study found that the contents of the message included issues of religious belief (aqidah), obedience to religion and the state (Shari'a ubudiyah and siayat) and ethics in associating with fellow humans even though foreigners and nonMuslims (akhlaq). In conclusion, that the message of da' wah in Tanbih TQN PP. Suryalaya, which was written in 1956 AD, keeps the guidance of life in religion and state.Keywords : Message, Da'wah; Tanbih TQN PP. Suryalaya
\end{abstract}

\title{
PENDAHULUAN
}

Berawal dari firman Alloh dalam al-Qur'an surat Al-Imran ayat 104 : "Hendaklah terdapat di antara kalian segolongan umat yang menyeru kepada kebajikan, menyuruh kepada yang maruf serta mencegah pada kemunkaran, merekalah orang- orang yang beruntung". Ayat ini menjadi dasar anjuran untuk melakukan dakwah bagi setiap orang muslim yang memiliki kemampuan berdakwah, baik malalui media (wasilah) tabliq, diskusi dan lainya (dakwah bil lisan) maupun berdakwah melalui media (wasilah) tulisan (dakwah bil qolam).

Menurut (An-Nabiry, 2008: 237-238), media dakwah ada enam macam, diantaranya: Pertama, dakwah melalui lisan (dakwah bil lisan); kedua, dakwah melalui tulisan (dakwah bil qolam); ketiga, dakwah melalui Audio visual; keempat, dakwah melalui Uswah dan qudwah hasanah (suri teladan) 
tingkah laku yang baik; kelima, dakwah melalui Lingkungan keluarga; keenam, dakwah melalui Organisasi Islam.

Dalam konteks zaman sekarang dakwah melalui tulisan (dakwah bil qolam) bisa diaplikasikan melalui bermacam-macam bentuk tulisan, diantaranya dengan menerbitkan majalah, buku, koran, bulletin dan lain sebagainya. Begitu juga dakwah bil qolam bisa melalui bentuk tulisan lainnya seperti wasiyat. Syaikh Abdulloh Mubarok bin Nur Muhammad Mursyid Thoriqoh Qodiriyah Naqsabandiyah (TQN)PP. Suryalaya silsilah ke-36 berwasiat kepada murid-muridnya melalui tulisan pada tahun $1956 \mathrm{M}$. Wasiat ini biasa disebut tanbih dan tanbih ini sejak dipublikasikan sampai sekarang ini selalu dibaca di setiap pengajian manaqib Tuan Syaikh Abdul Qodir Al-Jailani di lingkungan TQN PP. Suryalaya.

Dalam perkembangan dakwah di Indonesia akhir-akhir ini banyak mengalami pergeseran, awal mula Islam masuk Indonesia dibawa oleh wali songo menyampaikan pesan-pesan dakwah dengan ramah dan sopan melalui pendekatan dakwah sufistik (tasawuf), tetapi dewasa ini banyak pergeseran dalam mengemas dan menyampaikan pesan-pesan dakwah. Semula seeorang da'i tampak dengan sifat ramah dan sopan, kini banyak da'i tampak menakutkan dan berakhir membosankan, tentu hal itu tidak lepas dari pesan dakwah yang mereka kemas dan referensi mereka baca.

Dalam kajian ilmuan dakwah, pesan-pesan dakwah terbagi 3, yaitu pesan akidah, syariat dan akhlak. Oleh sebab itu, penulis tertarik untuk menganalisi pesan-pesan dakwah dalam tanbih Syaikh Abdulloh Mubarok Bin Nur Muhammad (Abah Sepuh) dari sudut pandang kajian keilmuan dakwah. Fokus penelitian ini adalah analisis isi pesan dakwah dalam tanbih TQN PP. Suryalaya.

Metodologi penelitian ini megunakan analisis isi kualitatif. Teknik pengumpulan informasi yang digunakan dalam riset ini ialah dengan 
Ahmadi

mencari informasi menimpa hal- hal yang berkaitan dengan masalahmasalah yang hendak diteliti berbentuk catatan, novel, pesan berita serta informasi penunjang lainya yang terdapat hubungannya dengan permasalahan riset.

\section{LANDASAN TEORITIS}

\section{Analisis isi (content analysis)}

Analisis isi merupakan metode penelitian untuk mendapatkan gambaran isi pesan komunikasi massa yang dilakukan secara objektif, sistimatik, serta relevan secara sisiologis. Penjelasan dalam analisisnya boleh saja memakai tata metode pengukuran kuantitatif ataupun kualitatif, ataupun keduanya sekalian (Nasution, 2002: 32).

Analisi isi digunakan buat mendapatkan penjelasan dari isi komunikasi yang di informasikan dalam wujud lambang. Tidak hanya demikian, analisis isi pula bisa digunakan untuk menganalisis seluruh wujud komunikasi seperti pesan berita, novel, puisi, lagu, cerita rakyat, lukisan, pidato, pesan, teater apalagi novel serta lain sebagainya (Rahmat, 2002 : 89). Selain itu dalam menganalisis isi, yang digunakan buat mendapatkan penjelasan dari isi pesan dakwah, apabila dakwah di informasikan dalam wujud lambang tersebut hingga unit analisis yang digunakan merupakan modul dakwah yang berisi tentang pesan aqidah, akhlak, serta Syariah (ibadah, muammalah, dan politik( syiasat)).

Metode Analisis isi menurut Hadari Nawawi dalam (Sujono dan Abdurrahman, 2005: 16-17) menyebutkan prosedur analisis ini dilakukan dengan langkah- langkah berikut:

1. Menyeleksi teks yang hendak diselidiki dengan mencermati: 
Analisis Isi Pesan Dakwah Dalam Tanbih TQN PP. Suryalaya

1) Menghubungi pihak yang berwenang buat menetapkan keyakinan jika analisis isi terhadap sesuatu novel teks hendak berguna;

2) Mengadakan observasi buat mengidentifikasi keluasan mengkonsumsi teks yang diartikan;

2. Menetapkan standar isi novel dalam bidang sebut dari segi teoris serta khasiat praktisnya.

3. Menyusun item- item yang spesial tentang isi dan bahas yang hendak diselidiki sebagai peralatan pengukur data. Buat itu diperlukan keahlin dalam bahasa yang digunakan hendak analisis.

4. Melaksanakan riset selaku berikut:

1) Menetapkan tata cara yang hendak ditempuh, apakah dicoba pada keselurhan isi novel, bab per bab, pasal demi pasal, memisahkan ilustrasi dengan teks dan sebagainya;

2) Melakuakn pengukuran terhadap teks secara kualitatif dan kuantitaf, menempatkan ilustrasi tertulis dan gambar serta uraian dan yang lain;

3) Membandingkan hasil pengukuran bersumber pada standar yang telah ditetapkan melalui item-item spesial yang telah disusun.

5. Merumuskan hasil analisis kuantitatif dengan mempergunakan perhitungan statistic yang relevan sebagaimana interprestasi isi novel, baik secara keseluruhan ataupun dari bagian ke bagian selanjutnya.

\section{Pesan Dakwah}

Secara estismologis ataupun bahasa, dakwah berasal dari bahasa Arab fiil madhi dari lafad " $d a^{\prime} a$ " (دعا), dan madarnya berupa lafad dakwatan (دعوة) artinya memanggil, mengundang, meminta, dan memohon (Munawwir, A.W. 1997: 406). Pada tataran aplikasi dakwah, dakwah harus melibatkan 3 faktor, yaitu: ada penyampai pesan, ada pesan. dan ada penerima pesan (M. Munir dan Wahyu Ilahi, 2009 : 17 ). Menurut M. Quraisy Shihab 
Ahmadi

(dalam Khazanah, 2007 : 25-26), istilah dakwah secara terminology, diartikan sebagai seruan atau ajakan kepada keinsyafan atau upaya mengubah situasi ke arah yang lebih baik dan lebih sempurna, baik dalam urusan pribadi maupun urusan kemasyarakatan.

Pesan dalam Islam yakni nasihat, permintaan, amanah yang wajib di informasikan kepada orang lain. Sedangkan pesan dakwah merupakan seluruh statment yang bersumber dari al- $\mathrm{Qu}^{\prime}$ an serta as- Sunnah baik secara tertulis, ataupun wujud pesan- pesan( risalah) (Tasmara, 1987 : 43). Dengan demikian dapat dikatakan bahwa pesan-pesan atau materimateri dakwah harus sampai kepada mad'u atau objek dakwah, adapun pesan dakwah menurut Wardi Bachtiar dalam bukunya "Metodelogi Penelitian Ilmu Dakwah", pesan- pesan dakwah yang bersumber dari alQur' an serta as- Sunnah bisa dikategorisasikan jadi pesan aqidah, pesan akhlaq, serta pesan syariat (Bachtiar, 1997 : 33-34).

\section{HASIL DAN PEMBAHASAN}

\section{Analisis Isi Pesan Dakwah Dalam Tanbih}

Analisis isi pesan dakwah dalam Tanbih TQN PP. Suryalaya ini menggunakan pedoman tiga kategori pesan dakwah, yakni kategori pesan Aqidah (Tauhid); kategori pesan Syariat (Fiqh); dan kategori pesan Akhlaq (Tasawuf). Untuk menguatkan data tentang pesan dakwah yang terkandung dalam Tanbih Syaikh Abdulloh Mubarok bin Nur Muhammad, penulis berusaha menganalisis isinya disertai referensi dari berbagai buku yang mendukung isi Tanbih tersebut. Adapun dalam analisis Tanbih ini tidak bermaksud diuji secara statistik kuantitatif, melainkan penulis hanya menguatkan datanya. Adapun pesan dakwah yang terkandung dalam Tanbih, dapat terlihat dalam setiap kalimat 
Analisis Isi Pesan Dakwah Dalam Tanbih TQN PP. Suryalaya

kemudian dianalisis secara detil. Pembahasan pesan dakwah dalam Tanbih akan dibahas secara rinci, adapun urutan pembahasan sebagai berikut :

\section{Pesan Akidah}

Pesan dakwah yang mengandung kategori Akidah, salah satunya Iman Qodha Qodhar Alloh. Adapun paragraf dalam Tanbih yang mengandung iman kepada Qodha Qodhar Alloh dapat dibaca dari kutipan Tanbih sebagai barikut :

".....karena mereka jadi fakir miskin itu bukannya kehendak sendiri, namun itulah kudrot Alloh Subhanahu wa ta'aala".

Sifat Qudrot adalah salah satu sifat Alloh yang ketujuh dari 20 sifat wajib kepada Alloh dalam ilmu tauhid. Qudrot ialah sifat wujudiyah yang qodim yang berdiri dengan dzat Alloh. Dengan sifat tersebut Alloh mewujudkan setiap perkara yang mungkin, dan meniadakannya atas ketetapan perencanaan yang terdahulu. Alloh maha suci dan maha luhur, dan Ia adalah dzat yang maha kuasa atas sesuatu yang mungkin wujudnya dan meniadakannya (Husain As-Saqof, Juz: 4, t.th : 10). Sebagaimana firmanNya: "Alloh adalah dzat yang menciptakan langit dan bumi"(QS. Al-Ahqof: 33)

Dalil aqliy atas qudrot Alloh ialah wujudnya alam ini, karena bila Alloh tidak kuasa niscaya Alloh itu lemah dari menciptakan alam ini. Maka mustahil bagi Alloh memiliki sifat 'Ajuz (lemah). Iman kepada Qodha' dan Qodar termasuk rukun iman yang ke enam. Seseorang belum dikatakan beriman apa bila ia belum meyakini dan mempercayai Qodha' dan Qodar Alloh ini. Dalam hadits Qudsi yang diriwayatkan oleh At-Tabrani dari Anas Ra, Alloh Ta'ala barfirman: "Siapa saja yang meridhoi Qodha dan Qodar-Ku (Alloih) dan ia tidak tabah pada ujian yang diberikan, maka ia disuruh mencari sesembahan Tuhan selain-Ku (Alloih)"(Hasyimi, 2005 : 121).

Dan haram hukumnya perbuatan maksiyat manusia disadarkan kepada Qodha dan Qodar Alloh (Husain As-Saqof, Juz: 4, t.th : 12). Makna iman 
Ahmadi

Qodha dan Qodar ialah meyakini dengan teguh bahwasanya setiap sesuatu yang baik maupun yang jelek semua itu Qodha dan Qodar Alloh. Sesungguhnya Alloh telah menetapkan semua perbuatan kita sejak zaman azali, baik itu yang dilakukan atau yang tinggalkannya. Alloh menentukan kita kehendak untuk menentukan memilih hal yang baik atau yang jelek. Oleh sebab itu kita tidak dipaksa atas melakukan sesuatu. Wajib kita ridho (rela) dengan qodha dan qodar Alloh.

\section{Pesan Syariah}

Pesan dakwah yang mengandung karegori Syariat, mencakup tentang ibadah (ubudiyah) dan politik (syiasat), diantaranya :

\section{“....., murid-murid hendaknya jangan sampai berbuat yang bertentangan dengan peraturan agama dan negara".}

Maksud Abah Sepuh tersebut, kita hidup di dunia ini mesti mentaati perintah Penciptanya berupa agama. Dan mentaati pengaturnya di muka bumi berupa negara, yakni aturan yang ditetapkan oleh negara yang dipimpin salah satu orang yang berhak mengaturnya, selama orang tersebut tidak bertentangan dengan perintah agama.

Prof. Dr. KH. Said Aqil Sirad berkata: Tuntutan manusia untuk mengimani kepada Tuhan tidak lepas dari landasan rasional maupun risalah ketuhanan (wahyu). Bahwa, realitas alam semesta ini mustail terjadi (eksis) tanpa ada pencipta dan pengaturnya. Bisa dibayangkan jikalau suatu negara tanpa presiden, provensi tanpa gubernur, kabupaten tanpa bupati, kecamatan tanpa camat dan kelurahan tanpa lurah, pasti sirna wilayah tersebut (Sirad, $1999: 44)$.

Ikrar umat beriman terhadap eksisitensi Tuhan berpengaruh dalam tiap langkah mereka. Berbeda dengan orang kafir, munafik, serta musyrik yang jiwanya keropos serta gersang dari sinar ilahi, karena setiap umat beriman mempunyai jalinan bathin (jiwa) yang kokoh antara mereka 
dengan Tuhan. Bahwa dengan perilaku penyembahan serta kehambaan mereka di hadapan Tuhan, menjadikan hidup mereka betul- betul hanya dipersembahkan untuk Sang Maha Pencipta alam semesta. Kepercayaan ini pada kesimpulannya membagikan legitimasi moral kepada mereka untuk menempuh kehidupan di dunia yang sementara. Sedangkan misi kholifah Tuhan tidak diberikan kepada makhluk lainnya kecuali kepada manusia yang dipercaya Tuhan untu mengatur serta mengelola dunia seisinya (Sirad, 1999 : 45).

Oleh sebab itu kita wajib mentaati pemimpin dunia, sebagaima firman Alloh Ta'ala : "taatilah Alloh, Rosul-Nya, dan ulil amri (pemerintah) di antara kalian" (Qs. An-Nisa': 59). Menurut tafsir Imam al-Maraghi, bahwa ayat di atas menjelaskan prinsip-prinsip pokok ajaran agama dalam bidang kekuasaan dan pemerintah serta sumber-sumbernya, yaitu: (1) perintah agar taat kepada Alloh Ta'ala. ditunjukkan dengan mematuhi kandungan al-Qur'anil Karim. (2) kewajiban taat kepada dan Rosululloh Shollollohu 'alaihi wasallam dengan mengikuti Sunnah Rosululloh Shollollohu 'alaihi wasallam. (3) taat kepada Ulil Amri, yakni taat kepada mereka yang diberi kepercayaan oleh umat seperti para ulama, cendik cendekia, pimpinan militer, penguasa, petani, industriawan, buruh, wartawan, dan sebagainya. (4) serta mengembalikan persoalan yang diperselisihkan kepada kaidah-kaidah umum yang terdapat dalam al-Qur'an dan Sunnah (Mustaqim, 2012 : 282).

Dan pesan syariat kalimat berikutnya :

\section{“.......murid-murid mesti mewujudkan kerelaan agama dan negara, taat kehadirat Ilahi yang membuktikan perintah dalam agama dan negara".}

Menurut Syaikh Abdulloh Mubarok (Abah Sepuh), seseorang bisa dikatakan taat kehadirat Ilahi dibuktikan melaksanakan perintah agama dan negara, sekalipun sebagian kelompok ummat taat kehadirat Ilahi 
Ahmadi

hanya berhenti taat perintah syariat saja, maksudnya mereka belum menerima pancasila sebagai dasar negara. Mereka menginginkan Islam secara formal sebagai dasar negara, padahal kemerdekaan Indonesia hasil dari perjuang secara bersama-sama dari ummat Islam, Kristen, Katholik, Budha dan Hindu dalam mengusir penjajah, tentu setelah Indonesia merdeka mereka bermusyawarah untuk merumuskan dasar negara dan berakhir dengan kesepakatan dasar negara "Pancasila".

Pada tahun 2011, bahkan ada sebagian kelompok Islam di daerah Karang Akhyar Jawa Tengah, menghormati bendera merah putih saat upacara hari senin menjadi masalah. Mereka mengklaim prilaku menghormati bendera adalah prilaku yang musyrik karena mengangungkan benda yang hal itu dilarang oleh agama.

Mereka tidak paham sejarah Islam, bahwasanya mengkat bendera dalam peperang sebagai simbol bahwa peperangan tetap berlanjut, sedangkan menurunkan bendera sebagai simbol peperangn berhenti. Kholid bin Walid panglima perang masa Nabi Shollollohu 'alaihi wasalllam sambil berperang Kholid bin Walid mengangkat bendera, demi mempertahankan perjuangan dalam melawan orang kafir, ia rela kedua lengan patah akibat sabetan pedang musuh. Awalnya musuh menyabet lengan kanannya saja dan bendera oleh Kholid bin Walid diangkat dengan kirinya lalu musuh menyabetkan pedangnya lagi ke lengan kirinya, sehingga kedua lengannya patah demi mempertahankan semangat juang dalam peperangan melawan musuh.

Bengitu juga tradisi mengkibarkan bendera merah putih di Indonesia sebagai bentuk bahwa negara Indonesia merdeka dan mempertahankan semangat juang kemerdekaan. Sedangkan kata musyrik yang artinya menyekutukan Alloh. Jauh-jauh kepada kepada bendera, terhadap ka'bah pun ternasuk musryik, kalau dipahami ka'bah disekutukan dengan Alloh. Semestinya kata "Menyembah" hanya pantas untuk Alloh, 
sedangkan terhadap ciptaan Alloh (makhluk), harus bermaksud menghormati. Sekalipun bermaksud mengangungkan, tentu tidak sama dalam mengangungkan Alloh dengan mengagungkan makhluk-Nya.

Padahal pancasila sendiri bagi umat Islam adalah dasar negara yang telah disepakati oleh para para pemimpin umat Islam bersama-sama tokohtokoh berbagai agama lainnya pada saat itu. Sebagaimana perjanjian yang telah disepakati Nabi sendiri dengan kaum Kuffar dan Musyrikin Mekah, perjanjian yang dikenal perjanjian Hudaibiyah. Oleh sebab itu, mempertahankan dan mengisi perjanjian merupakan kewajiban. Sebagaimana disebutkan dalam Al-Qur'an: "Hai orang-orang yang beriman, penuhilah aqad-aqad itu"(QS. Al-Maidah: 1).

Dalam ayat tersebut menunjukkan dengan terang bahwa umat Islam diperintahkan oleh Alloh untuk memenuhi janji terhadap akad-akad yang telah dibuatnya. Dalam hal ini jelas, Pancasila adalah perjanjian luhur yang dibuat oleh wakil-wakil nya bersama para tokoh yang lain. Perjanjian itu penting untuk ditunaikan, artinya dipelihara dan diisi secara bertanggung jawab oleh umat Islam, agar umat Islam juga ikut terlibat menuntun bangsa ini. Perjanjian itu mengandaikan tatanan bangsa yang damai (dar ash-shuluh) dan keharusan mewujudkan keadilan sosial.

Pesan Abah Sepuh ini lahir dari latar belakang permasalahan di tengah umat Islam sendiri dalam memahami Pancasila sebagai dasar negara. Dimana, permasalah tersebut memuncak dengan penyerangan fisik, kelompok yang anti Pancasila menyerang kepada kelompok yang mendukung Pancasila sebagai dasar negara. Abah Sepuh dan muridmuridnya sangat menentang pemberontakan kelompok Darul Islam (DI)/TII yang didalangi oleh Kartosuwiryo. Bahkan di Pondok Pesantren Suryalaya sendiri mendapat serangan dari DI/TII, terhitung lebih dari 48 kali. 
Sedangkan menurut abah Aos, pada masa itu sekelompok umat Islam yang tidak puas dengan Pancasila sebagai asas negara, diiringi sokongan sebagian ulama Jawa Barat menghendaki berdirinya negeri Pasundan.“ Abah Sepuh salah satunya ulama Jawa Barat yang menentang berdirinya negeri Pasundan (Wawancara Abah Aos Jam 20: 30, 20-6-2018 M).

Tanbih yang diluncurkan oleh Syaikh Abdullah Mubarok bin Nur Muhammad (Abah Sepuh) untuk memotivasi murid-muridnya yang sedang maupun yang akan datang, lebih luasnya lagi untuk umat Islam dan lainnya, supaya taat agama dan negara sebagai bentuk ketaatan kepada Sang Ilahi.

Kometmen taat kehadirat Ilahi dibuktikan melaksanakan perintah agama dan negara dalam tanbih ini, dilaksanakan oleh penerusnya (silsilah ke37 mursyid TQN PP. Suryalaya) sebagaimana isyaroh Abah Anom, beliau pernah berkata: "Apabila umat Islam Indonesia tidak mau menerima Pancasila sebagai dasar negara, akan gigit jari" (Wawancara Abah Aos, Jam 21: 30, 31 Mei 2018 M.).

Begitu juga Abah Aos muryid TQN PP. Suryalaya silsilah ke - 38, beliau sangat taat kepada peraturan yang telah ditetapkan oleh Tanbih, seperti kewajiban memiliki KTP (Kartu Tanda Penduduk), Pada malam Jum'at tanggal 6 Agustus 2015, Abah Aos mengingatkan tamu-tamunya yang ketahuan tidak memiliki KTP. Abah Aos sangat tegas menyatakan kepada tamu-tamunya, "Jangan datang ke sirnarasa selama belum memiliki KTP". Dan juga Abah Aos selalu mengigatkan murid-muridnya yang tidak memiliki Sim, tidak boleh membawa kendaraan apapun selama belum memiliki Sim. Seperti inilah kometmen guru-guru Mursyid TQN PP. Suryalaya terhadap Negara dari masa ke masa.

Sepanjang sejarah, komunitas Thoriqoh Qodiriyah Naqsyabadiayah (TQN )PP. Suryalaya sikap politiknya selalu berada di posisi koalisi 
Pemerintah, dan tidak pernah bersikap oposisi dengan pemerintah. Abah Sepuh mursyid TQN silsilah ke 36 dikenal dekat Presiden RI pertama Bung Karno, Abah Anom mursyid TQN silsilah ke -37dikenal dekat dengan Presiden RI setelahnya, seperti Bapak H. Suharto, Gusdur hingga H. Susilo Bambang Yudoyono (SBY). Abah Aos mursyid TQN silsilah ke -38 dalam sikap politik sebagaimana leluhur TQN PP. Suryalaya selalu ada di bagian koalisi Pemerintah. Abah Aos berkata, "Akan selalu bersama pemerintah seperti Abah Sepuh dan Abah Anom".

Demikian pula sepanjang sejarah, komunitas TQN PP. Suryalaya tidak pernah bergambung dengan komunitas manapun yang melakukan aksi unjuk rasa, apapun permasalahannya. Dalam pandangan TQN PP. Suryalaya menyuarakan pendapat atau menentang kebijakan pemerintah, tidak tepat bila disampaikan dengan cara unjuk rasa, lebihlebih bersikap anarkis hingga merusak fasilitas umum, mengganggu kelancaran lalu lintas, dan menghambat perkembangan ekonomi. Sebaiknya menyampaikan pendapat kepada penguasa itu dengan cara baik sebagaimana yang dianjurkan nabi, yaitu musyawaroh. Abah Aos sebagai mursyid TQN PP. Suryalaya silsilah ke-38 ketika tidak sependapat dengan kebijakan pemerintah (penguasa), beliau menyampaikan pendapatnya dengan cara mengirimkan surat kepada penguasa (Presiden). Hal itu dilakukan ketika Abah Aos tidak sependapat dengan kebijakan pemerintah, pada saat pemerintah membatasi kegiatan keagamaan di masjid-masjid di masa pandemic covid 19.

Syaikh` Abdul Aziz bin' Abdullah bin Baaz rahimahullahu Ta' ala mengatakan dalam kitab Majmu' Fataawa Ibnu Baaz, 8/ 210, “Tidaklah ada dalam manhaj salaf( manhaj ahlus sunnah), menviralkan kejelekan pemerintah serta menyebut-nyebutkannya di atas mimbar-mimbar pidato, demikian itu hanya melahirkan penggulingan pemerintah. Serta pula memunculkan rakyat tidak ingin mendengar serta taat terhadap pemerintah dalam perihal kebaikan, berikut memunculkan pemberontakan yang berakibat pada kemudharat serta jauh 
Ahmadi

dari kemanfaatan. Sebaliknya, konsep yang diikuti ahlus sunnah dengan menyampaikan nasihat secara empat mata antara ia dengan penguasa, mengirimkan pesan ke penguasa, ataupun lewat ulama yang dapat mengantarkan pesan nasihatnya, sehingga dapat memberikan arahan kepada penguasa menuju arah kebaikan".

Demikian itu dilalukan sebagaimana petunjuk nabi, beliau bersabda, "Siapa saja yang hendak menasihati penguasa dalam suatu masalah, maka janganlah menasihatinya secara terang-terangan. Akan tetapi, ambillah tangannya dan menyepilah dengannya. Jika dia penguasa menerimanya, itulah yang diinginkan. Jika tidak, maka dia telah menunaikan kewajibannya"(HR. Ahmad 3/403, dan Ath-Thabrani dalam Musnad Asy-Syamiyyiin 2/94).

Dan berdasarkan hadits yang diriwayatkan oleh Muslim dari Wail bin Hujr Ra :"Kami bertanya, wahai Rasulullah," Apa pendapatmu bila para pemimpin kami tidak penuhi hak kami, tetapi mereka senantiasa memohon haknya( selaku pemimpin)?" Hingga dia bersabda," Dengarkan serta taatilah( pemimpin negeri kamu), sebab sesungguhnya dosa mereka merupakan tanggungan mereka serta dosa kamu merupakan tanggungan kamu" (Muslim, no: 3433).

\section{Pesan Akhlaq}

Pesan dakwah yang mengandung kategori Akhlak diantaranya adalah:

1. Akhlak kepada Alloh

Adapun paragraf Tanbih mengandung akhlak kepada Alloh, meliputi taubat, do'a, Raja' (tidak berhenti-henti mengharap anugrah Alloh), dan berusaha menghindar dari berbagai bentuk penyelewengan.

Berikut ini teks tanbih tentang pesan akhlak kepada Alloh :

"Insafilah hai murid-murid sekalian, janganlah terpaut oleh bujukan nafsu, terpengaruh oleh godaan syetan". 
Insaf ialah sadar akan kekeliruannya dan bertekad akan memperbaiki dirinya. Istilah lainnya dari insaf ialah thobat, thobat berasal dari bahasa arab, fiil madhi thaba yuthibu, masdarnya berupa thauba atau thaubatan yang artinya menyesal atau bersumpah tidak mengulangi lagi (Munawwir, 1997 : 140).

Hakikat taubat adalah mengangungkan perintah Alloh Yang Maha Haq 'Azza Wajalla dalam situasi apapun. Oleh karena itu sebagian ulama sufi semoga rahmat Alloh tercurakan kepada mereka, berkata: Seluruh kebaikan ada pada dua kalimat: mengangungkan perintah Alloh 'Azza Wajalla dan menyanyangi makhluq-Nya'. Setiap yang tidak mengagungkan perintah Alloh dan tidak menyayangi makhluq-Nya maka ia jauh dari Alloh (Tajul Arifin, 2005 : 130).

Sebagaimana firman Alloh Ta'ala:"Orang-orang yang takut kepada kebesaran Tuhannya dan menahan diri dari keinginan hawa nafsunya, maka sungguh baginya surga tempat tinggalnya". (QS. An-Nazi'at: 4041)

Dan Abah Sepuh berpesan :

“......Waspadalah akan jalan penyelewengan terhadap perintah agama dan negara, agar meneliti diri dari bisikan iblis".

Bisikan Iblis atau setan sangat berbahaya dan menyesatkan manusia dari perintah Tuhannya, dengan ini kita harus waspada dan berusaha membentengi diri dari godaanya dengan menyibukkan diri dengan zikir. Sebagaimana firman Alloh dalam hadits qudsi: "Laa ilaha ila Alloh adalah benteng-Ku, siapa yang memasuki benteng-Ku, ia akan selamat dari adab-Ku" (Tajul Arifin, 2005:122)

Karena kalau tidak membentengi diri dengan dzikir iblis akan menggangunya, sebagaimana janji iblis yang disebutkan di dalam Al-Qur'an: "Iblis menjawab: "Karena Engkau telah menghukum saya 
tersesat, saya benar-benar akan (menghalang-halangi) mereka dari jalan Engkau yang lurus (QS. Al-A'raf: 16-17).

Dan do'a beliau kepada murid-murid :

".....Semoga ada dalam kebahagian, dikaruniai Alloh Subhanau wa ta'aala kebahagian yang kekal dan abadi".

Inilah bentuk keperihatinan seorang guru mursyid kepada muridmuridnya pada saat itu, sekarang maupun yang akan datang, tiada lain harapan dalam do'anya kecuali untuk kebahagian muridnya, yakni kebahagiaan yang abadi, bukan kebahagian yang sifatnya sementara yang dimurkai Alloh Subhanahu wata'ala. Seorang mursyid di zamannya seperti seorang nabi di tengah-tengah kaumnya, begitu juga dalam do'anya mengikuti teladan nabinya terhadap ummatnya.

Kebahagian yang kekal tersebut tidak dapat diukur dengan banyaknya harta, pangkat, dan jabatan, tentu hal itu tidak akan dapat diperoleh kecuali setelah ikhlas dalam menjalankan perintah Alloh dan menjauhi larangannya. Sebagaimana misi Sang Pencipta menciptakan makhluk-Nya tiada lain kecuali untuk beribadah kepada-Nya dengan hati yang tulus. Sebagaimana firman-Nya: "Dan aku tidak menciptakan jin dan manusia melainkan supaya mereka mengabdi (beribadah) kepada-Ku"(QS.Adz-Dzariyat: 56)

2. Akhlak kepada sesama manusia

1) Akhlak kepada pemimpin dan kepada orang yang lebih tinggi derajatnya

Berikut ini teks tanbih tentang pesan akhlak kepada pemimpin :

"Pun pula semoga pimpinan negara bertambah kemulian dan keagungannya".

Beliau mengajarkan kepada murid-muridnya menghormati para pemimpin negara dengan berdo'akannya, supaya mereka bertambah kemuliannya, karena kemulian seorang pemimpin 
menjadi poin pertama untuk memperoleh kesuksesan dalam memimpinnya.

Menurut (Sirad, 1999 : 48-49), rakyat (al-ummah) sebagai pihak yang dipimpin harus memiliki prilaku dan akhlaq yang baik pula terhadap pimpinannya, antara lain :

Pertama, mentaatinya, apabila sesuai dengan garis Alloh dan Rosul-Nya; berdasarkan firman Alloh Ta'ala: "Hai orang-orang yang beriman, taatilah Allah dan taatilah Rasul (Nya), dan ulil amri di antara kamu"(QS. Al-Nisa': 59).

Kedua, berdisiplin; berdasarkan firman Alloh Ta'ala dalam alQur'an surat Al-Hasyr ayat 7.

Ketiga, siap membela tanah air dan bangsa; berdasarkan firman Alloh Ta'ala dalam al-Qur'an surat Al-Anfal ayat 60.

Keempat, menjaga persatuan dan kesatuan; berdasarkan firman Alloh Ta'ala dalam al-Qur'an surat Ali Imran ayat 103.

Kelima, berkesadaran untuk melahirkan pemerintah yang bersih dan wibawa, dengan senantiasa mengontrol dari segala penyelewengan dan tindakan ketidakadilan, bahkan bila perlu mengadakan oposisi, jika stuasi mengharuskannya; berdasarkan firman Alloh Ta'ala dalam al-Qur'an surat Al-Ashr ayat 3).

Keenam; menghindari perbuatan yang membinasakan dan bertidak menghakimi sendiri, serta akhlaq ummah yang lain (akhlaq-akhlaq yang lain).

Demikian pula tentang menghormati orang yang lebih tinggi kedudukan derajatnya, Abah Sepuh berwasiat kepada muridmuridnya, sebagaimana teks tanbih sebagai berikut :

"Terhadap orang-orang yang lebih tinggi dari pada kita baik dhohir maupun batin mesti dihormati".

Hendaknya kepada siapapun dan dimanapun, tidak melupakan bersikap akhlak mulia, mereka yang dikenal maupun mereka 
yang tidak dikenal. Karena setiap manusia memiliki hak-hak sesama yang harus dihormati, sebagaimana sabda Nabi Shallallohu'alahi wasalam dalam hadits yang diriwayatkan oleh Bukhari dari Abu Hurairah Ra., beliau bersabda: "Siapa saja yang tidak menyayangi mereka yang lebih muda di antara kami dan tidak mengerti hak orang yang lebih tua, maka dia bukan termasuk golongan kami"(Hasyimi, 2005 : 173).

2) Akhlak kepada orang yang sederajat

Sebagaimana teks tanbih tentang pesan akhlak kepada orang yang sederajat sebagai berikut :

\section{"Terhadap sesama yang sederajat dengan kita dalam segala-galanya, jangan sampai terjadi persengketaan, dan semestinya bersikap rendah hati, bergotong royong dalam melaksanakan perintah agama dan negara".}

Saling menghormati antar sesamanya merupakan akhlaq yang dianjurkan oleh Rosululloh dalam pergaulan di tengah-tengah masyarakat. Cara-cara tersebut ditunjukkan lewat sikap dan perilaku masing-masing orang dalam pergaulan di tengahtengah masyarakat. Islam memiliki konsep yang jelas, bagaimana hidup bermasyarakat yang baik, perhatikan hadits yang diriwayatkan oleh Muslim dari Abu Hurairah Ra., Rosulullah Shollollohu 'alaihi wasallam bersabda: "Barang siapa beriman kepada Alloh dan hari akhir hendaklah memuliakan tetangganya"( Hasyimi, 2005 : 173).

Berikut ini adab bergaul yang harus dilaksanakan agar keharmonisan berteman tercapai, diantaranya :

- Saling menghormati antar sesama manusia, sekalipun berasal dari suku maupun negara yang berbeda; berdasarkan firman Alloh Ta'ala dalam al-Qur'an surat Al-Hujarat ayat 13. 
- Saling bekerjasama dan tolong menolong dalam hal kebaikan; berdasarkan firman Alloh Ta'ala berdasarkan firman Alloh Ta'ala dalam al-Qur'an surat Al-Maidah ayat 2.

- Saling Mengasihi; berdasarkan firman Alloh Ta'ala dalam alQur'an surat Ash-Shura ayat 23.

- Saling melindungi; berdasarkan firman Alloh Ta'ala dalam alQur'an surat Al-Anfal ayat 72.

- Saling menasehati; berdasarkan firman Alloh Ta'ala dalam alQur'an surat Al-Balad ayat 17.

3) Akhlak kepada orang yang derajatnya lebih rendah Sebagaimana teks tanbih tentang pesan akhlak kepada orang yang lebih rendah sebagai berikut :

"Terhadap orang-rang yang keadaannya di bawah kita, janganlah hendak menghinakannya, berbuat tidak senonoh, atau bersikap angkuh".

Salah satu dari sekian penyakit hati yang dianggap sebagai penghalang menuju Alloh ialah bersikap angkuh, sombong dan dholim terhadap sesama manusia. Oleh sebab itu kaum sufi berjuang terus menerus agar hatinya bebas dari sifat sombong dan tidak mendholimi orang-orang yang lemah.Sebagaimana firman Alloh Ta'ala: "Dan janganlah kamu berjalan di muka bumi ini dengan sombong"(QS. Al-Isro': 37).

Kesombongan menurut imam Ghozali, ada dua macam. Yakni kesombongan secara bathiniyah dan kesombongan lahiriyah. Kesombongan batin adalah suatu tingkah laku pada jiwa, sedangkan kesombongan lahir adalah suatu perbuatan yang timbul dari gerak gerik tubuh. Jika sifat sombong itu terwujud dalam tingkah laku dan amal perbuatan maka seseorang dianggab takabbur. Jika tidak tampak, maka dalam diri seseorang terdapat sifat sombong. Sungguh pangkal kesombongan itu adalah perangai dalam jiwa. Yaitu merasa 
bangga dan cenderung agar ia diperhatikan orang lain yang disombonginya. Dan sifat sombong pada dasarnya merupan keinginan untuk menarik perhatian orang lain tentang yang disombongkannya (Al-Qalami, t.th : 79).

Oleh karena itu, imam Ghozali menyatakan bahwa kesombongan, kemengahan, ketinggian, dan kebesaran itu tidak pantas, kecuali untuk Sang Pemilik Kekuasaan. Sedangkan manusia berhak memiliki dan merasa lemah, hina, dan tidak berkuasa sedikit pun tentang sesuatu. Lalu apa yang harus disombongkan. Alloh Ta'ala berfirman dalam hadits Qudsi: "Keagungan adalah kain sarung-Ku dan kesombongan adalah kain seledang-Ku. Maka barangsiapa melawan-Ku, niscaya Aku pecahkan dia"(Hadits Qudsi).

4) Akhlak kepada fakir miskin

Demikian pula Abah Sepuh menganjurkan menghormati orang yang lebih rendah sebab kefakiran maupun kemiskinan, sebagaimana teks dakwah berikut ini :

"Terhadap fakir miskin harus kasih sayang, ramah tamah, serta bermanis budi. Bersikap murah tangan mencerminkan bahwa hati kita sadar".

Tanpa diragukan lagi kalau keberadaan kalangan dhuafa' semacam fakir miskin, serta yang yang lain merupakan dua golongan masyarakat yang berhak untuk mendapatkan perhatian dan pemeliharaan. Alloh Subhanahu wata'ala banyak sekali menyebutkan di dalam Al-Qur'an tentang anjuran untuk menyayangi dan berbuat baik kepada dua golongan tersebut. Sebagaimana firman-Nya : "Sesungguhnya kebajikan itu ialah beriman kepada Alloh, hari akhir, malaikat-malaikat, kitab-kitab, nabinabi, dan memberikan harta yang dicintainya kepada kerabatnya, anakanak yatim, orang-orang miskin..."(Al-Baqarah: 177) 
Hadits yang diriwayatkan oleh Ibnu La-al dari Ibnu Umar, Rasululloh Shollollohu 'alaihi wasallam bersabda: "Bagi setiap sesuatu ada kuncinya, kunci surga ialah mencintai orang-orang miskin dan orang-orang fakir"(Hasyimi, 2005 : 139) Dan hadits yang diriwayatkan oleh Dailami dari Ibnu Umar, nabi bersabda: "Pemuda yang dermawan lagi berakhlak baik, lebih dicintai Alloh daripada orang tua ahli ibadah yang kikir" (Hasyimi, 2005 : 102)

Dermawan adalah salah satu penawar sifat rakus dan menjadi sumber dari segala kebaikan. Kebalikan sifat dermawan adalah sifat kikir (pelit). Adapun sifat pelit menjadikan seseorang kufur terhadap nikmat Alloh, bertindak tidak jujur, tidak adil, menipu, ghosab (memakai barang milik orang lain), dan mencuri. Bahkan bisa lebih dari itu, sehingga ia berani melakukan pembunuhan.

5) Akhlak kepada sesama manusia sekalipun orang asing maupun non muslim.

Sebagaimana teks tanbih tentang pesan akhlak kepada manusia sekalipun non muslim sebagai berikut :

"Demikianlah sesungguhnya sikap manusia yang penuh kesadaran sekalipun kepada orang asing karena mereka itu masih keturunan Nabi Adam a.s."...hal ini Abah Sepuh berpedoman pada firman Alloh dalam Al-Qur'an surat Isro ayat $70^{\prime \prime}$.

Abah Sepuh menjelaskan ayat ini dengan dijelaskan dengan surat Al-Maidah ayat 2 tentang anjuran tolong menong dalam hal kebajikan dalam perintah agama dan negara dan jangan tolong dal hal dosa dan permusuhan.

Sebagaimana sikap Rosulullah Shollollohu 'alaihi wasallam adalah sosok yang toleran dan menghormati pemeluk agama lain. Hal ini sudah dijelaskan dalam al-Qur'an, Alloh Ta'ala berfirman: "Maka berkat rahmat Alloh engkau Muhammad berlaku lemah lembut terhadap mereka. Sekiranya engkau bersikap keras lagi 
berhati kasar, tentulah mereka menjauhkan diri dari sekitarmu" (QS Al-Imran: 159).

Nabi Muhammad Shollollohu 'alaihi wasallam sebagai pemimpin yang terbaik di dunia, bukan hanya dating dari klaim umat muslim sendiri, akan tapi beliau juga diakui oleh para tokoh ilmuan non-muslim. Pada masa hidup beliau, walaupun kaum kafir Quraisy memusuhinya, beliau tetap bersikap rendah hati, sopan santun, lemah lembut, adil, sabar, dan pemaaf.

Ketika beliau tinggal di Mekah, orang-orang kafir Quraisy senantiasa mencaci maki dan menghina bahkan perlakuan kasar terhadap fisik beliau, tapi beliau tetap sabar, tawakkal sambil mendoakan mereka, supaya mereka diberi petunjuk oleh Alloh Ta'ala. Selain itu beliau tetap menyampaikan risalah kepada mereka dengan bijaksana dan baik, sesuai dengan firman Alloh Ta'ala: "Serulah (manusia) kepada jalan Tuhan-mu dengan hikmah dan pelajaran yang baik dan bantahlah mereka dengan cara yang baik". (QS An-Nahl: 125)

Begitu juga umar bin Khottob kholifah kedua menggantikan Abu Bakar. Diceritakan kholifah kedua ini berjalan-jalan menyusuri kota Madinah semacam kebiasaannya untuk mengamati rakyatnya. Dia kaget kala memandang seseorang lelaki Yahudi tua rentak yang tergeletak di pinggir jalur. Ia setelah itu bertanya kepadanya apa yang buatnya semacam itu? Nyatanya orang Yahudi tersebut menderita sebab jatuh miskin. Umar sangat pilu melihatnya, serta memutuskan untuk memberikan makanan secara khusus dari Baitul Mal untuk menolong supaya orang tua tersebut bisa hidup secara layak. Bukan hanya demikian, Umar pula membebaskannya dari kewajiban membayar pajak negeri( jizyah). 
Contoh lain dari jiwa kemanusiaan Umar terhadap penduduk di wilayah yang ditaklukkan pasukan Islam. Kemudian Umar tidak ingin lagi menjadikan mereka sebagai budak terhadap penduduk setempat. Salah satu perkataan Umar yang sangat populer sampai saat ini merupakan perkataannya kepada Amru bin Ash:"Kenapa kamu masih menjadikan penduduk tersebut sebagai budak, padahal ibu- ibu mereka melahirkan kondisi merdeka?"(Suryawinata dkk., 2015: 50)

Demikian pula anjuran Abah Sepuh tentang sikap toleransi kepada orang yang berbeda ada agama, beliau mengutip surat Al-Kafirun ayat 6, sebagaimana teks tanbih sebagai berikut:

\section{"Adapun soal keagamaan, itu terserah agamanya masing- masing mengingat surat A1-Kafirun ayat 6, "Agama-mu untuk kamu, agama-ku untuk aku". Maksudnya, jangan sampai terjadi perselisihan, wajiblah kita hidup rukun dan damai, saling harga-menghargai, tetapi janganlah sekali-kali ikut campur".}

Sebagaimana yang disebutkan Syaikh Abdulloh Mubarok dalam Tanbih ini, hanya dalam urusan keimanan dalam beragama dengan orang lain yang beda agama jangan ikut campur, sedang dalam masalah sosial mesti saling berbuat baik, saling menghormati, dan saling tolong-menolong. Hal ini telah dicontohkan oleh penerusnya, seperti Abah Anom sering menerima tamu dari kalangan non Muslim, bahkan beliau memiliki dokter pribadi non Muslim. Berikut abah Aos, Ibu Elka Pagestu seorang non muslim ketika menjabat mentri perwisata di era Presiden Susilo Bambang Yudoyono berkunjung di kediaman Abah Aos Pesantren Sirnarasa, Aos menyambutnya dengan memberikan serlendang di pundaknya sebagai bentuk penghormatan. Dengan cara demikian suriteladan sikap 
toleransi Abah Aos kepada non muslim sebagaimana pesan Tanbih.

Juga sikap seperti itu dilakukan ulama lainnya, Gus Dur menceritakan salah satu gurunya, Gus Miek melalui trandensi keimanan tidak lagi memandang" kesalahan" kepercayaan orang beragama ataupun keyakinan orang lain. Ayu Wedayanti yang Hindu diperlakukan sama dengan Neno Warisman yang muslimah, sebab dia percaya kebaikan sama terletak pada 2 orang penyanyi tersebut. Banyak orang Katolik jadi pendengar setia wejangan Gus Miek seusai sema' an( membaca al- Qur' an hingga tamat secara bergantian). Kerinduannya kepada realisasi kemampuan pada diri manusia inilah inilah yang bagi aku menjadikan Gus Miek supernatural. Bukan sebab dia menyalahi syarat hukum- hukum alam. Akan tetapi dianggap Super, sebab ia sanggup menanggulangi seluruh berbagai jurang pemisah serta tembok penyekat antara sesama manusia. Natural, sebab yang dia harapkan cumalah kebaikan bagi manusia. (Wahid, 2010 : 93)

Dalam sejarah ada riwayat tentang Sayyidina Umar akan menguasai Palestina. Pembesar gereja di sana tidak akan menyerahkan kunci gereja kalau bukan kholifah sendiri yang datang. Kala itu Sayyidina Umar datang ke Palestina dan masuk gereja. Saat tiba waktu sholat, Sayyidina Umar keluar gereja dan sholat di luar (Sirad, 1999 : 146).

Warga non Muslim di Khalifaan Islam masa Dinasti Abbasiyah, pada awalnya status dzimmi hanya mencakup kelompok yang memiliki kitab suci, yaitu Yahudi, Nasrani dan Sabiin, namun kemudian diperluas, seperti seperti telah kita bahas sehingga meliputi para penganut Zoroaster, Sabiin, Harran, dan kelompok lainnya. Mereka semua ditempatkan pada posisi yang sama 
dengan kelompok keagamaan yang terikat dengan perjanjian untuk saling menghormati kebebasan beragama (HITTI, 2005 : 441).

Di kota maupun di desa, orang dzimmi berpengang teguh pada budaya, dan memelihara bahasa asli mereka: budaya dan bahasa Aram serta Suriah di Suriah dan di Iraq, budaya dan bahasa Iran di Persia, dan bahasa serta budaya Kaptik di Mesir. Kebanyakan dari mereka yang masuk Islam kemudian pindah ke kota. Bahkan di kota sekalipun, orang Kristen dan orang Yahudi banyak yang menduduki jabatan penting, seperti bagian keuangan, administrasi, dan jabatan profesional lainnya. AlMu'tadhil (892-902) mengangkat seorang Kristen sebagai kepala lembaga Pertahanan. Kebanyakan dokter pribadi pribadi para khalifah, seperti yang kita bahas, adalah pengikut Gereja Nestor (HITTI, 2005 : 441-442).

Pada masa Achmad bin Thulun pada tahun $320 \mathrm{H}$ sedang berkuasa di Mesir, pendeta berpidato di masjid, kiayi ataupun ulama berpidato di gereja. Di Libanon, terdapat novel yang terbit tentang filsafat agama. Bab- bab tentang Islam itu yang menulis George Konawati, orang Kristen. Begitu pula kebalikannya, novel filsafat Kristen yang menerangkan tentang Kristen, yang menulis merupakan Dokter. Adib Saleh, orang Islam). Era Sultan Harun Al- Rosyid, orang Kristen dibikinkan gereja, orang Yahudi dibikinkan tempat Ibadah. Hingga saat ini Irak masih terdapat tempat ibadah orang Yahudi. Itu semenjak era Harun Al- Rosyid (Sirad, 1999 : 136).

Begitu juga Islam melarang sikap menghujat terhadap kelompok orang lain, sebagaimana firman Alloh Ta'ala: "Hai orang- orang yang beriman, janganlah sekumpulan orang pria merendahkan 
kumpulan yang lain, boleh jadi yang ditertawakan itu lebih baik dari mereka"(QS. Al-Hujarat: 11).

Perilaku kalangan Muslim kepada pemeluk agama lain jelas, sebagaimana ditegaskan dalam al- Qur' an, ialah berbuat baik kepada mereka serta tidak mejadikan perbedaan agama sebagai alasan untuk tidak menjalani hubungan kerjasama dengan mereka, lebih- lebih berperilaku tidak toleran kepada mereka, Islam datang tidak melarang orang Islam berbuat baik kepada siapa saja selama mereka tidak memusuhi orang Islam, tidak melecehkan simbol- simbol keagamaan ataupun mengusir kalangan muslimin dari negaranya.

Imam Bukhori menggambarkan dari Anas, Ketika Nabi wafat, pakaian beliau masih digadaikan pada orang Yahudi untuk membiayai keluarganya, padahal beliau pada waktu itu masih bisa meminjam dari para sahabatnya. Akan tetapi, hal itu dikerjakannya sebagai suriteladan bagi umatnya dalam hal kemanusiaan. Yusuf Qaradhawi lebih lanjut menggambarkan kalau Nabi Shollollohu' alaihi wasallam menerima hadiahhadiah dari orang- orang non Muslim, memohon pertolongan dari mereka baik dalam setuasi nyaman ataupun perang melawan musuh, sejauh perihal itu dilakukan dalam lingkup tolong-menolong serta bukan untuk tujuan lain yang merugikan serta membahayakan (Mustaqim dkk., 2012 : 184 -187).

Sebelum Islam masuk ke Madinah, yaitu Suku Aus serta suku Khazraj, keduanya ikut serta persaingan serta pertikaian yang tiada hentinya. Walaupun sudah banyak peperangan di antara keduanya serta sudah banyak pula darah yang ditumpahkan, tidak terdapat pihak yang bisa mendamaikan kedua suku tersebut. Tetapi sehabis Islam masuk Madinah, berkat Rosululloh Shollollohu' alaihi wasallam, Suku Aus serta suku 
Analisis Isi Pesan Dakwah Dalam Tanbih TQN PP. Suryalaya

Khazraj yang sepanjang sejarah salalu saling perang dan berakhir keduanya damai. Bahkan keduanya menjadi pembela setia Rosululloh dalam berdakwah sehingga mereka disebut dengan kaum Anshor (Suryawinata dkk., 2015 : 42).

Dari sekian isi pesan pesan-pesan dakwah dalam tanbih, setelah dianalisis dengan dari berbagai sumber, bahwa isi pesan dakwah Tanbih ini sebagaimana pesan Al-Qur'an dan hadits, sekaligus isi pesan tanbih ini selaras dengan pemikiran para tokoh Islam zaman dahulu dan para tokoh Islam setelahnya. Semuanya mencerahkan akan pemahaman tentang kehidupan beragama dan bernegara, dan sekaligus menciptakan mental pemikiran akan kesiapan hidup rukun dengan berbagai bangsa, sekalipun seluas jagat raya. Dengan demikian agama datang bukan mengajarkan untuk saling bermusuhan diantara makhluk ciptaan Tuhan, akan tetapi agama datang mengajarkan untuk saling mengenal sesama ciptaan Tuhan, saling memberikan manfaat, sekaligus mengajak mereka bersama-sama kembali kepada Tuhan yang menciptakannya.

\section{PENUTUP}

\section{Kesimpulan}

Dalam penelitia ini menunjukkan bahwa isi pesan dakwah tanbih adalah bimbingan hidup beragama dan bernegara, meliputi masalah keyakinan dalam beragama (aqidah), ketaatan terhadap agama dan negara (syariat) dan etika dalam bergaul sesama muslim maupun non muslim (akhlaq).

Isi pesan dakwah dalam Tanbih ini mencakup pesan aqidah, pesan syariat dan pesan akhlaq, diantaranya:

1. Pesan aqidah, terdiri dari imana kepada qodha dan qodhar.

2. Pesan Syariat, diantaranya: 
1) Ubudiyah, seperti taat kepada Alloh dan menjauhi laranga-Nya, menjauhi bujukan hawa nafsu, godaan setan, dan bertaubat.

2) Syiayat (politik), seperti taat terhadap aturan negara dan menjauhi larangannya.

3. Pesan Akhlaq, diantaranya :

1) Akhlaq kepada Alloh; seperti berdo'a, Raja' (tidak berhenti-henti mengharap anugrah Alloh), dan berusaha menghindar dari berbagai bentuk penyelewengan.

2) Akhlaq kepada sesama manusia, diantaranya:

- Akhlaq kepada pemimpin dan orang yang lebih tinggi derajatnya.

- Akhlaq kepada orang yang sederajat.

- Akhlaq kepada orang yang lebih rendah.

- Akhlaq kepada fakir-miskin.

- Akhlaq kepada sesama manusia sekalipun orang asing maupun non muslim.

\section{Saran}

Setelah penulis menyelesaikan penelitian ini, penulis ingin memberikan beberapa saran kepada para pembaca:

1. Kepada pembaca, jadikanlah isi pesan tanbih ini sebagai referensi berfikir dan bertindak dalam beragama maupun bernegara dan tanbih ini akan tetap eksis dalam mengadapi perkembangan pemikiran yang sedang dan akan.

2. Seiring perkembangan zaman para da'i hendaknya mengemas dakwah lebih kreatif, menarik dan aktual, sehingga dapat membangkitkan animo mad'u untuk memperhatikan pesan dakwah yang disampaikan.

3. Kepada para akademisi jangan ragu untuk melahirkan karyakarya yang bernuansa Islam, dan mempublikasaikan secara luas, 
Analisis Isi Pesan Dakwah Dalam Tanbih TQN PP. Suryalaya karena hal itu merupakan bagian dari dakwah yang sangat mulia dan lebih lama masanya.

\section{DAFTAR PUSTAKA}

Al-Qalami, A. F. (t.th), Ajaran Makrifat Siti Jenar, Surabaya : Pustaka Media.

An-Nabiry, F. B. (2008), Meniti Jalan Dakwah, Jakarta: AMZAH.

Bachtiar, W. (1997), Metodelogi Penelitian Ilmu Dakwah, Jakarta: Logos Wacana Ilmu.

Hasyimi, A. (2005), Muhtar al- Hadits, Surabaya : Al-Harmain Jaya, Jalan Kali Mas.

Husain As-Saqof, A.S. (t.th), al-'Aqoidi ad-Diniyah, Juz: 4, Surabaya : Maktabah Muhamad bin Ahmad Nabhan Waauladihi.

HITTI, P. K. (2005), Historis of The Arabs (alih bahasa: R. Cecep Lukman Yasin dan Dedi Slamet Riyadi), Jakarta : PT Serambi Ilmu Semesta.

https://tirto.id > Humaniora, Khalifah yang Membangun Gereja Suci $\mathcal{E}$ Makam Yesus, diakses jam 20: 30, tgl 25 Juni 2018.

Khazanah, S. U. 2007), Berdakwah Dengan Jalan Debat, Purwokerto : STAIN Purwokerto Press.

Mustaqim, A. dkk., (2012), Buku Khotbah Jum'at, Yogyakarta: Laboratorium Agama Masjid Sunan Kalijaga UIN.

Munawwir, A.W. (1997), Kamus al-Munawwir Arab-Indonesia Terlengkap, (Surabaya : Pustaka Progressif.

Munir, M. dan Wahyu Ilahi. (2009), Manajemen Dakwah, Jakarta: Kencana Prenada Media Group.

Nasution, Z. (2002), Sosiologi Komunikasi Massa, Jakarta: Pusat Penelitian Universitas Terbuka. 
Rahmat, J. (2002), Metode Pemiukiran Komunikasi, Bandung: PT. Rosdakarya.

Rahmad, J. (2001), Metode Penelitian Komunikasi: Dilengkapi Contoh Analisis Statis, Bandung: Remaja Rosdakarya.

Sirad, S. A. (1999), Islam Kebangsaan Fiqih Demokrasi kaum Santri, Jakarta: Penerbit Pustaka Cianjur Percetakan Fatma Press.

Sirad, S.A. (1999), Kiai Menggungat, Mengadili Pemikiran Kang Said, Jakarta: Penerbit Pustaka Ciganjur, Percetakan Fatma Press.

Suryawinata A. A. dkk. (2015), Pendidikan Perdamaian di Pesantren Berperspektif Islam dan HAM, Jakarta : UIN Syarif Hidayatulloh.

Sujono dan Abdurrahman. (2005) Metode Penelitian: Suatu Pemikiran Dan Penerapan, Jakarta: PT. Rincka Cipta.

Tasmara, T. (1987), Komunikasi Dakwah, Jakareta: Gaya Media Pratama.

Tajul Arifin, A. (2015). Miftahus Shudur (Anding Mujahidin (ed.). Jakarta: PT. Laksana Utama.

Wahid, A. (2010), Gus Dur Menjawab Perubahan Zaman, Warisan Pemikiran KH. Abdurrahman Wahid, Jakarta : Kompas Buku. 